\title{
AS MINERALIZAÇÕES AURIFFERAS DA REGIÃO DE MARA ROSA (GO)
}

\author{
HOMERO LACERDA*
}

\begin{abstract}
In Mara Rosa region there is a number of gold mineralized areas that are being mined by prospectors. The main purpose of this work is to describe each mineralized area in order to define types and controls of gold mineralization. A generalized model for gold metallogenesis in the area is also proposed. The stratigraphy of the area comprises: Mara Rosa Supracrustals and GraniteGneiss Complex, both of Archean to Early Proterozoic Age; Tertiary/Quaternary Lateritic Cover; and Quaternary Alluvial Deposits. Nine of the 14 gold occurrences studied are stratabound and occur in Mara Rosa Supracrustals; two are vein and pipe like quartz bodies in Mara Rosa Supracrustals and Granite-Gneiss Complex; and three are elluvial gold deposits overlying Mara Rosa Supracrustals. Although gold placer deposits have not been studied here, they have been mined in the area. It is proposed that syngenetic and low-grade gold mineralization are associated with interflow graphitic sediments, intermediate tuffs, and chert belonging to Mara Rosa Supracrustals. Folding and metamorphism resulted in local enrichments inside these source beds originating stratabound gold mineralization. Epigenetic and structurally controlled vein and pipe like ore bodies originated at least in part by remobilization of pre-existing singenetic mineralization. Elluvial gold mineralization was originated by weathering of weakly mineralized Mara Rosa Supracrustals rocks, whereas alluvial placer deposits were originated by reworking of all three pre-existing mineralization types. The studied area illustrates the permanence of gold mineralization in a given area by successive reworking of an early gold concentration both by endogenous and exogenic processes. In fact, a NNE trending belt contains most of known gold mineralization of the area.
\end{abstract}

INTRODUÇÃo A exploração de ouro na região de Mara Rosa, situada na porção central do Estado de Goiás (Fig. 1), remonta ao período colonial, quando a lavra de aluvióes auriferas deu origem ao povoado de Amaro Leite. A atividade garimpeira na área iniciou-se por volta de 1980 e no final de 1983 , no auge, ali trabalhavam cerca de 500 . pessoas distribuídas em 14 garimpos. A partir de dados oficiais sobre comercialização de ouro na região e de dados sobre a evolução das atividades de garimpagem na área (Machado et al. 1980, Machado et al. 1981, Campos et al. 1985), estima-se uma produção da ordem de $200 \mathrm{~kg}$ de ouro para o período de 1980 a 1984.

Esta nota tem por objetivo contribuir para o conhecimento geológico das mineralizações auríferas da região, pela descrição das frentes de garimpagem. A posição das mineralizaçðes no contexto geológico regional foi abordada pela compilação de um mapa geológico em escala 1:100.000, apoiada na realização de perfis geológicos regionais, no qual foram plotadas as ocorrências descritas. As áreas com maiores concentrações de garimpos foram mapeadas em escala $1: 50.000$ ou $1: 25.000$ visando a definiçãoo do contexto geológico local das mineralizações. Alguns garimpos foram mapeados em escala 1:2.000 com objetivo de definir a morfologia dos corpos mineralizados e suas relaçōes espaciais com as rochas encaixantes. Esses trabalhos foram complementados pela observação de seçð̄es delgadas e polidas, estas últimas tanto de rocha como de concentraçzes de minerais pesados.

A figura 1 ilustra, esquematicamente, o contexto geologico regional da área estudada, que será descrito a seguir.

O Complexo Granito-Gnáissico (Danni \& Fuck 1981, Marini et al. 1984) é constituído por ortognaisses graníticos, tonalíticos e granodioríticos, em meio aos quais ocorrem núcleos granito-granodioríticos. Neste complexo observam-se faixas miloníticas balizando lineamentos estru- turais de direção $\mathrm{N} 20-40 \mathrm{E}$, além de feições migmatíticas subordinadas. Esta unidade apresenta evolução policíclica, do Arqueano ao Proterozóico Superior, e nela estariam englobados terrenos que serviram de substrato para os greenstone belts arqueanos, assim como terrenos gerados durante a evolução pós-greenstone belts da região.

Os greenstone belts ocorrem na região de Crixás-Pilar de Goís (Fig. 1), sob a forma de calhas encaixadas no Complexo Granito-Gnáissico (Danni \& Ribeiro 1978, Sabóia 1979). Na área de Crixás, o greenstone belt é constituído por três unidades (Sabóia 1979, Sabóia et al. 1981): basal, constituída essencialmente de rochas metavulcânicas ultramáficas; média, constituída essencialmente por rochas metavulcânicas máficas; e de topo, essencialmente metassedimentar pelfítica e química. Se existe consenso em considerar esta sequêencia como um greenstone belt arqueano, o mesmo não ocorre em telação à sequiência vulcano-sedimentar que aflora na região de Mara Rosa (Fig. 1). Machado et al (1981) e Machado (1981) consideram-na como sendo o prolongamento do greenstone belt de Crixás-Pilar de Goiás enquanto Ribeiro Filho (1981) acredita tratar-se de uma sequêencia vulcano-sedimentar de idade proterozóica inferior.

o Grupo Araxá, de idade proterozóica média, é constí tuído essencialmente de mica xistos, aos quais se associam quartzitos próximo à base de cálcio-xistos e mármores em direção ao topo.

GEOLOGIA A estruturação da área estudada obedece a um rumo NE, com alternância de faixas vulcano-sedimentares (Sequêencia Mara Rosa) e faixas granitóides (Complexo Granito-Gnáissico), ambas parcialmente recobertas por lateritas (Fig. 2). 


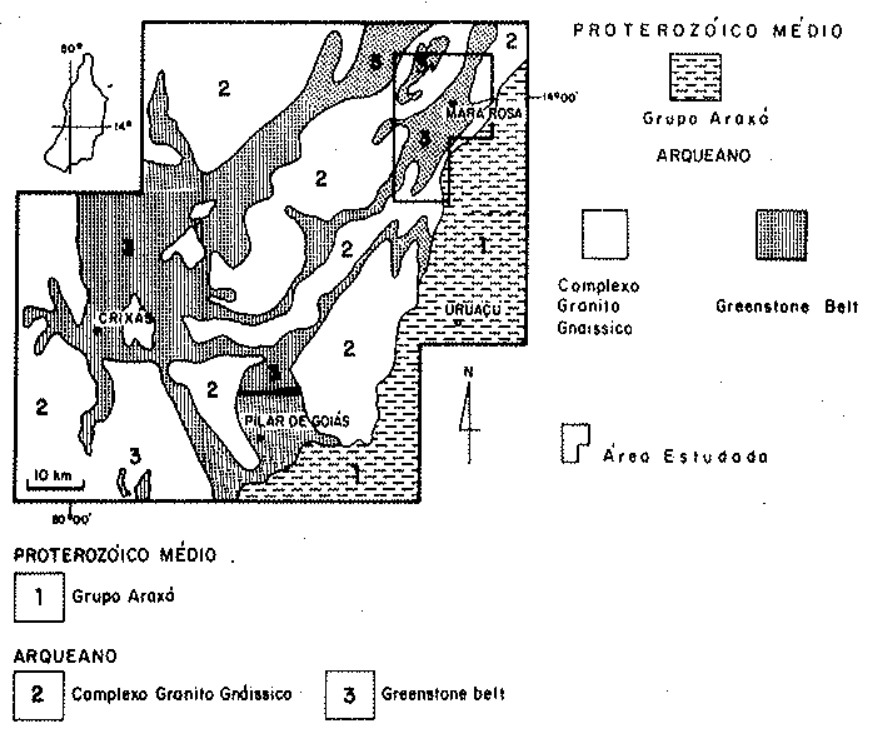

Figura $l$ - Contexto geológico regional da área estudada (modificado de Machado 1981)

Estratigrafia Segue-se a descrição sumária das unidades estratigráficas da area, da base para o topo, segundo o modelo estratigráfico aqui adotado.

SEQÜENCIA MARA ROSA Ribeiro Filho (1981) propôs a denominação informal de Sequuência Mara Rosa para as faixas vulcano-sedimentares que ocorrem na região estudada e que correspondem ao Conjunto Vulcano-Sedi. mentar de Machado et al (1981). A idade dessas rochas é controvertida e pode ser arqueana (Machado et al. 1981) ou proterozóica inferior (Ribeiro Filho 1981). De acordo com os litotipos predominantes a Seqüência Mara Rosa pode ser dividida em:

- Gnaisses e mica xistos: São as unidades rochosas predominantes, estando representadas por biotita gnaisses, horblenda-biotita gnaisses, muscovita gnaisses, muscovitabiotita xistos, muscovita xistos, granada-muscovita-biotita xistos e, subordinadamente, mica xistos a cianita e/ou estaurolita.

- Anfibolitos: Estão representados por epídoto anfibolito, quartzo-epídoto anfibolito, plagioclásio anfibolito e clinopiroxênio anfibolito, contendo pequenas intercalaçžes de xistos magnesianos, mais abundantes no canto noroeste $\mathrm{da}$ área.

\section{COMPLEXO GRANITO-GNAISSICO Este complexo} é constituído por ortognaisses tonalíticos, granitos e milonitos de composição granítica (Fig. 2). Suas relações estratigráficas com a Sequiência Mara Rosa são controvertidas (Ribeiro Filho 1981, Machado et al. 1981), mas a presença de xenólitos de rochas desta seqüência nos granitóides daquele complexo sugere que ele seja mais recente.

Os ortognaisses tonalíticos têm granulação grossa, foliação concordante com a direção da Seqüuência Mara Rosa e contêm inclusర̃es de anfibolito.

Os granitos têm granulação média a grossa e apresentam, geralmente, foliação incipiente, podendo, freqüentemente, ser considerados como protomilonitos.
Machado et al. (1981) descrevem, nestas rochas, inclusões e restos de teto (roof-pendants) de gnaisses da Sequiência Mara Rosa.

Milonitos de composição granítica, contendo intercalações de mica xistos com espessuras aparentes varian. do do metro a centenas de metros, ocorrem na porção $\mathrm{SE}$ da área estudada (Fig. 2). Os mica xistos são localmente grafitosos e contêm intercalações de quartzitos micáceos bandados e ortoanfibolitos, sendo interpretados como supracustais pertencentes à Sequência Mara Rosa. Os milonitos podem representar supracrustais milonitizadas ou granitóides milonitizados. Considera-se a segunda hipótese a mais provável, com base nas seguintes observaçôes: existência, a NE e ao longo do mesmo rumo, de granitos milonitizados (protomilonitos) com inclusões e restos de teto (roof-pendants) de xistos e gnaisses, podendo representar a mesma unidade, porém menos deformada; presença, nos milonitos, de porfiroclastos de quartzo + feldspato com textura granular, podendo representar fragmentos de granito que sobreviveram ao processo de milonitização; e presença, dentro da Seqüência Mara Rosa, de veios graníticos dobrados e apresentando uma foliação milonítica.

INTRUSIVAS MAFICAS-ULTRAMAFICAS Ocorrem em corpos de dimensठ̃es quilométricas (Fig. 2), intrusivos na Sequuência Mara Rosa e nos ortognaisses tonalíticos do Complexo Granito-Gnáissico, sendo constituídos por gabro, hornblendito e diorito (Ribeiro Filho et al 1978, Machado et al. 1981).

COBERTURAS TERCIARIO-QUATERNARIAS Estão representadas pela cobertura detrítico-laterítica terciária-quaternária e pelas aluviōes quaternárias.

Geologia estrutural Nas rochas da Seqüência Mara Rosa a fase $F_{1}$ se manifesta por meio de dobras isoclinais deitadas, com espessamento apical, eixo N15W/20SW e plano axial $\mathrm{N} 30 \mathrm{~W} / 30 \mathrm{NW}$. Tais dobras são freqüentemente intrafoliais e provocaram a transposição do acamamento $\left(S_{0}\right)$ das supracrustais. A foliação plano-axial $S_{1}$ \& uma xistosidade definida pela isorientação de biotita, muscovita e hornblenda. Porfiroblastos de granada são tardi a pós-tectônicos em relação a $F_{1}$, enquanto os porfiroblastos de estaurolita e cianita são pós-tectônicos em relação a $F_{1}$, indicando um metamorfismo na fácies anfibolito.

Nos ortognaisses tonalíticos do Complexo Granito-Gnáissico, a fase $F_{1}$ se manifesta através de dobras isoclinais, discerníveis graças à existência, nestas rochas, de zonas mais ricas em minerais máficos. Estas dobras têm seu plano axial marcado pela foliação dos ortognaisses, concordante com a foliação $S_{1}$ das rochas da Seqüência Mara Rosa.

Feiçбes miloniticas ocorrem, ocasionalmente, nas rochas da Sequiência Mara Rosa e nos granitos e ortognaisses tonalíticos do Complexo Granito-Gnáissico. Nos contatos entre as duas unidades estas feições estão sempre presentes. São, obviamente, sempre bem marcadas nos milonitos de composição granítica. A foliação milonítica $\left(S_{m}\right)$ é concordante com a foliação plano-axial $S_{1}$, estando ambas deformadas pelas dobras da fase $F_{2}$. A observação de biotita, muscovita e clorita sin-milonitização indica que esta deformação se deu na fácies xisto verde. Este evento de milonitização pode ser tardi- $F_{1}$ mas, na falta de evidências mais seguras, será considrado separadamente $\left(F_{m}\right)$. 
As dobras da fase $F_{2}$ são anisópacas, geralmente fechadas e, mais raramente, isoclinais. Elas deformam $S_{1}$ e $S_{m}$ apresentando eixos com atitudes $\mathrm{N} 20-40 \mathrm{~W} / 30 \mathrm{NW}$. Mostram vergência para SE e são, portanto, praticamente co-axiais com as dobras $F_{1}$. Nos litotipos mais ricos em mica, desenvolveu-se uma foliação plano-axial $S_{2}$ do tipo clivagem de crenulação, em cujos planos ocorrem muscovita e, mais raramente, biotita e clorita. As dobras desta fase foram observadas principalmente na porção $\mathrm{SE}$ da área, nos xistos da Seqüência Mara Rosa e nos milonitos do Complexo Granito-Gnáissico. A esta fase de deformação parece corresponder um metamorfismo na fácies xisto verde que, juntamente com a milonitização acima referida, seria o responsável pelas freqüentes feições de retrometamorfismo observadas, tais como alteração da hornblenda em tremolita e clorita, da granada em biotita e clorita, da cianita em muscovita etc.

Seguem-se duas fases de dobramentos, representadas por dobras isópacas, fechadas, com eixos N50-70E/20SW $\left(F_{3}\right)$ e dobras isópacas, suaves, com eixos N50-80W/ $40 \mathrm{NW}$ e planos axiais verticalizados $\left(F_{4}\right)$, observadas na Sequiência Mara Rosa e nos ortognaisses tonalíticos do Complexo Granito-Gnáissico. Os falhamentos mais importantes têm direção $\mathrm{NE}$ sendo cortados por falhas de direção NW. As falhas com direção NE são balizadas por veios de quartzo e, mais raramente, por brechas de esmagamento e representam reativações de antigas zonas de cisalhamento. Este fato é demonstrado pelo exame das brechas descritas

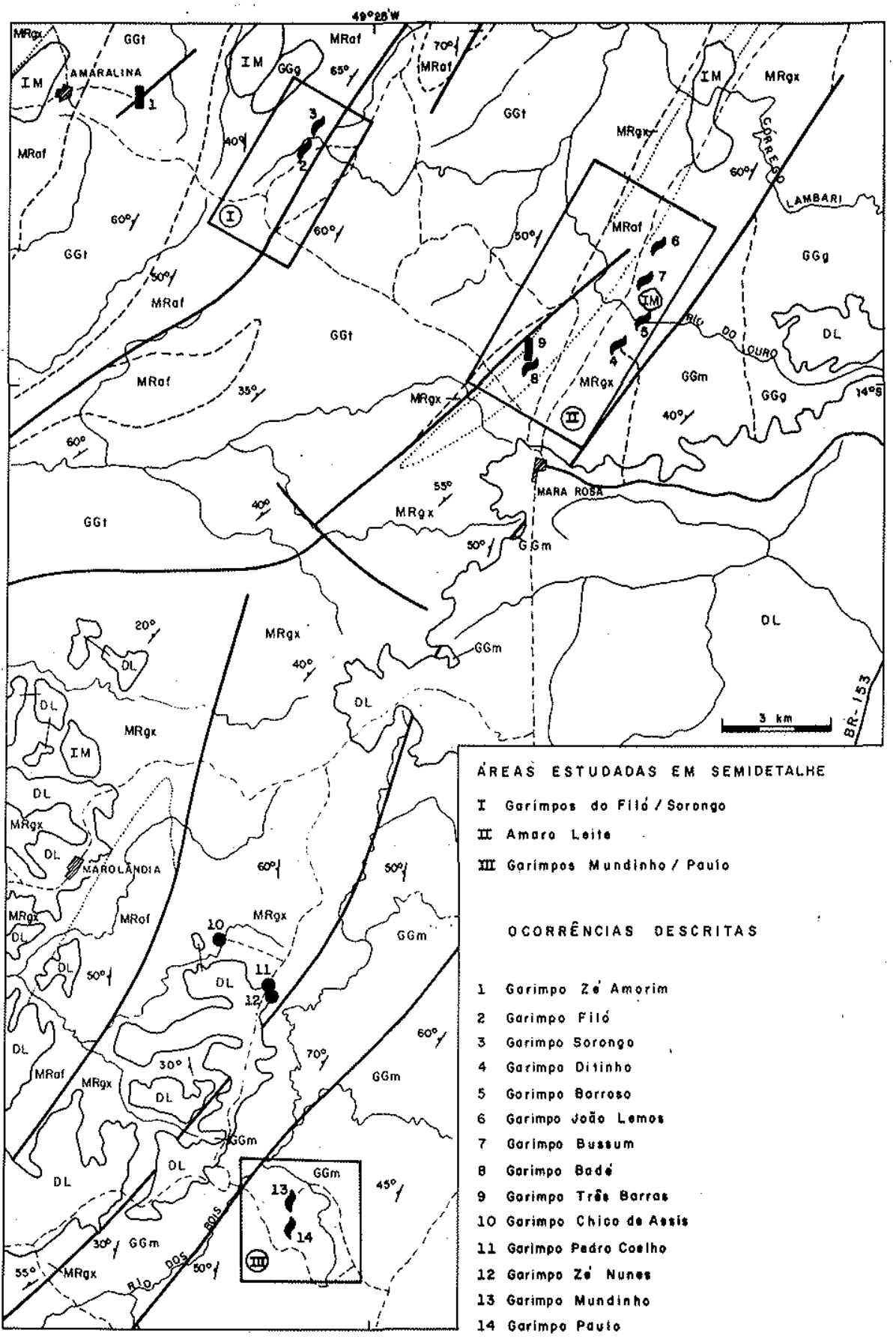

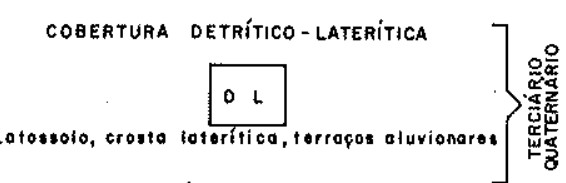

INTRUSIVAS MÁFICAS/ULTTRAMÁFICAS

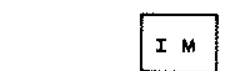

Gobro, hornblondilo, diorito

COMPLEXO GRANITO - GNÁISSICO

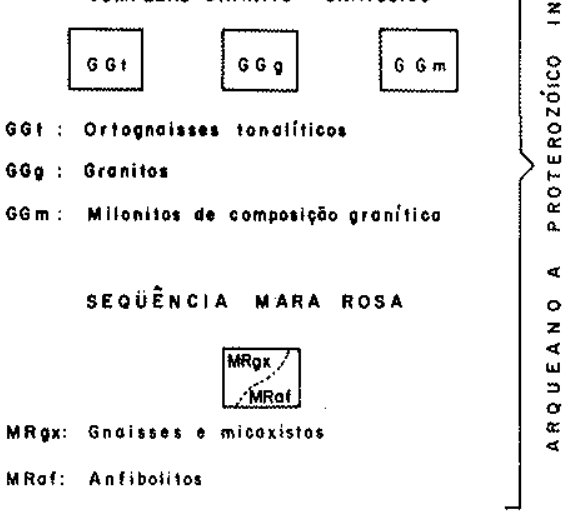

cootato,tacefodo onde inferido

Contato litólogico

Fotho

$/ 40^{\circ}$ Foliaģäo

- Mineralizaçāo aurifera primária estratitorme

Dineralizaçõo aurítero primório fitaneana

- Mineralizaçdo aurifora secundária eluvionar

$\square$ Áreos estudadas em semidetolhe

F rede de drenogem

$\int$ Rodovio asfoltado

Estrada carrofável

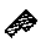

Cidade ou poroodo

$$
4^{N}
$$

Figura 2 - Geologia da área estudada (compilado e modificado de Ribeiro Filho et al. 1978 e Machado et al. 1981) 
por Ribeiro Filho et al (1978), constituídas por fragmentos angulosos de milonito de composição granítica em matriz de granulação muito fina, sem orientação, constituída de argilomineral, quartzo, carbonato e feldspato. A presença dos fragmentos de milonito na brecha indica a superposição de deformações rúpteis, representadas por falhas balizadas por brechas de esmagamento, a deformações de natureza dúctil, representadas por zonas de cisalhamento balizadas por milonitos (Sá \& Hackspacher 1982).

MINERALIZAÇÓES AURIFERAS Após uma revisão dos trabalhos anteriores sobre as mineralizações auríferas da região, serão descritas as ocorrências estudađas e designadas pelos nomes dos respectivos garimpos.

Trabalhos anteriores Machado et al. (1981) descreveram as mineralizaçós da área de Amaralina (Fig. 2) como estando relacionadas a um nível de metachert contendo segregaçőes quartzosas e intercalações de rocha grafitosa. Segundo esses autores, a camada de metachert está intercalada em anfíbolitos com teores anômalos de ouro e ocorre em zona de falha, o que teria propiciado a remobilização do ouro nas encaixantes e sua concentração local. Os mesmos autores descreveram vestígios de antigos trabalhos de mineração de ouro nos arredores do povoado de Amaro Leite (Fig. 2). Ali ocorreriam "xistos filonitizados que sofreram processos de metassomatismo (carbonatação e cloritização), dando origem a cálcio-clorita xistos, clorita-cálcio xistos e granada-biotita-plagioclásio xistos calciferos", contendo disseminações de pirita e calcopirita. Segundo os autores citados, "os processos de metassomatismo talvez tenham sido os responsáveis ainda pela remobilização e concentração de minerais sulfetados, muito freqüentes no local, e, quiçá, também do ouro". Ainda na área de Amaro Leite estão situadas as aluvióes aurfferas mais importantes da região, no Rio do Ouro e Córrego Lambari, objetos de exploração no período colonial.

Mineralizações da área de Amaralina Serão descritas aqui as ocorrências situadas na porção noroeste da área, próximo ao povoado de Amaralina (Fig. 2).

GARIMPO ZE AMORIM A ocorrência está situada no canto noroeste da área, cerca de $2 \mathrm{~km}$ a leste do povoado de Amaralina (Fig. 2). A mineralização ocorre em zona de cisalhamento de direção $\mathrm{NE}$, onde o ortognaisse tonalítico do Complexo Granito-Gnáissico está transformado em milonito, constituído de porfiroclastos de plagioclásio e de hornblenda, numa matriz de granulação fina, composta de quartzo, epidoto, sericita e clorita. A mineralização ocorre em blocos métricos de quartzo maciço, que contêm localmente até $5 \%$ de pirita, espalhados numa área de cerca de $50 \mathrm{~m}^{2}$, tratando-se, provavelmente, de um veio. Ao microscópio mineragráfico, a pirita aparece em grãos envoltos por limonita enquanto o ouro ocorre em grãos de 10 a 20 micra, sob duas formas: livre e associado ao quartzo; ou como inclusões na pirita (Prancha 1, Foto 1).

\section{GARIMPOS FILO E SORONGO Na área onde ocorrem} as mineralizaçðes em epígrafe predominam róchas da Seqüência Mara Rosa, em contato tectônico com ortognaisses tonalíticos. Observa-se ainda um corpo granítico intrusivo na Sequêencia Mara Rosa (Fig. 3).
A Seqüência Mara Rosa, encaixante das mineralizações auríferas, pode ser subdividida nas seguintes unidades litoestratigráficas:

- Epidoto anfibolito: Nesta unidade predominam anfibolitos de cor verde, granulação fina, com laminação milimé. trica a centimétrica. Existem litotipos constituídos essencialmente por anfibólio (hornblenda e tremolita), epidoto e clinopiroxênio, e litotipos onde, além desses minerais, ocorre também plagioclásio em proporçẫo significativa. A composição mineralógica e a presença de grãos de plagioclásio zonados indicam uma origem ortometamórfica para esses anfibolitos.

- Xistos magnesianos: São representados por clorita xisto, tremolita xisto e tremolita-clorita xisto que ocorrem sob a forma de uma camada e para os quais é proposta uma origem a partir de lavas ultramáficas.

- Quartzito grafitoso, anfibolito e magnetita-anfibólio-granada quartzito: Esta unidade será descrita juntamente com as mineralizaçōes auríferas a ela associadas.

- Plagioclásio anfibolito: São rochas de cor verde e cinza-esverdeado, granulação fina a grossa, maciças e incipientemente foliadas, com textura granoblástica e compostas de hornblenda e plagioclásio, com quartzo subordinado. Epidoto pode ou não estar presente, o mesmo ocorrendo em relação ao clinopiroxênio. $O$ plagioclásio está frequientemente zonado indicando o caráter ortoderivado destas unidades, a partir de rochas máficas. Intercalados nos anfibo. litos ocorrem biotita-hornblenda gnaisse e magnetita-anfibollio-granada quartzito.

$\mathrm{Na}$ porção nordeste da área existem duas frentes de garimpagem, conhecidas como garimpos do Sorongo e do Filó. A estas duas pode-se acrescentar uma terceira, abandonada quando da realização deste trabalho, situada na porção sudoeste da área, junto à estrada que liga Mara Rosa a Amara lina e descrita por Machado et al. (1981).

As ocorrências do Filó e do Sorongo estão encaixadas na mesma unidade litoestratigráfica (Fig. 3) e sâo geologicamente semelhantes. Assim sendo, será descrito somente o garimpo do Filó, onde a explotação é realizada por uma escavação de $30 \times 70 \mathrm{~m}$, com profundidade máxima de $15 \mathrm{~m}$ e orientação NE (Fig. 4), concordante com o rumo das unidades litoestratigráficas. Neste local, a unidade portadora da mineralização pode ser dividida em três níveis, descritos a seguir, devendo-se ressaltar que nas espessuras indicadas não foram eliminados os efeitos de dobramentos:

- "Camada" Grafitosa $(10 \mathrm{~m})$ : É constituida por alternâncias centimétricas e métricas de quartzitos puros, quartzitos grafitosos e sericita-quartzo xistos grafitosos. Ao micros. cópio, o quartzito grafitoso apresenta textura granoblástica orientada e composição à base de quartzo e grafita, com sericita bastante subordinada.

- Anfibolito $(35 \mathrm{~m})$ : São rochas intemperizadas, foliadas, de cor amarelo-ocre a vermelho. No garimpo do Sorongo estas rochas contêm intercalaçōes decimé. tricas de granada-anfibólio quartzitos com sulfetos disseminados. 
- Magnetita-granada-anfibólio quartzito $(3 \mathrm{~m})$ : $\mathbf{E}$ uma rocha de cor marrom, granulação fina, laminação milimétrica, cuja alteração resulta em material rico em óxidos de manganês. Ao microscópio, mostra textura granoblástica e composição à base de quartzo, granada, tremolita-actinolita $\mathrm{e}$ opacos (magnetita e/ou sulfetos). Trata-se, provavelmente, de um metachert ferro-manganesífero.

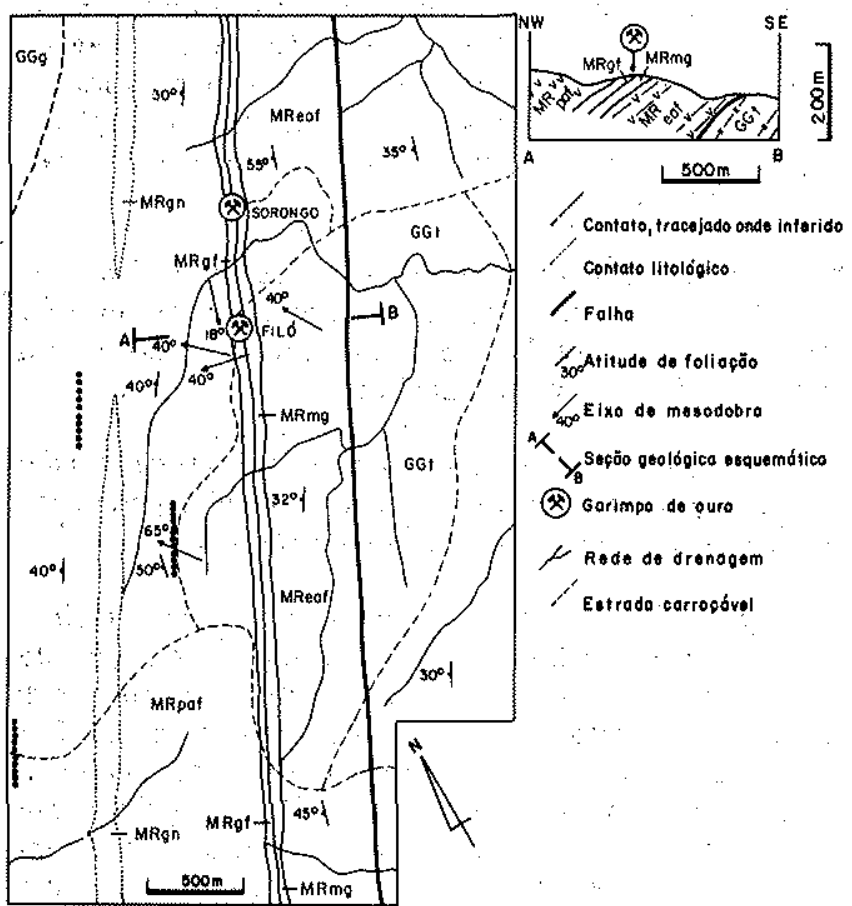

COMPLEXO GRANITO - GNAIISSICO

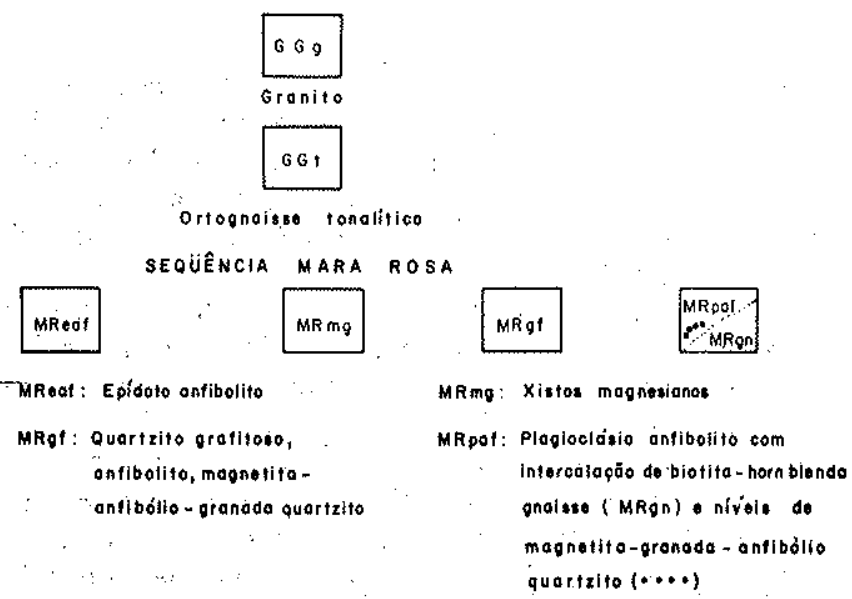

Figuira 3 - Contexto geológico dos garimpos Filó e Sorongo (ver localização da área na figura 2)

As mineralizaçбes auríferas explotadas nos garimpos do Filó e do Sorongo são de natureza stratabound, compreendendo uma faixa de cerca de $5 \mathrm{~m}$ de espessura, englobando parté da "camada" grafitosa e parte do anfibolito (Fig. 4). São de preferência explotados os níveis ricos em lentes de quartzo de segregação, de espessura centimétrica a decimétrica, concordantes com a foliação $S_{1}$, onde se observam ouro live e algum sulfeto. Ámostras de canal do garimpo do Filo apresentaram valores entre 0,5 e $5,0 \mathrm{ppm}$ de ouro (Machado et al 1981).

Para o estudo mineragráfico foram preparadas seçres polidas do concentrado de minerais pesados das lentes de quartzo de segregação, do granada-anfibólio quartzito intercalado nos anfibolitos e do quartzito grafitoso. Neste último, além das lamelas de grafita, estão presentes peque. nos grãos de pirita. No granada-anfibólio quartzito, o opaco predominante é a pirrotita, à qual se associam calcopirita, pirita e esfalerita. Alguns dos grãos de calcopirita estão recobertos por uma película de covelita. Os sulfetos aparecem em grãos isolados, xenomorfos, ou em agregados alon-

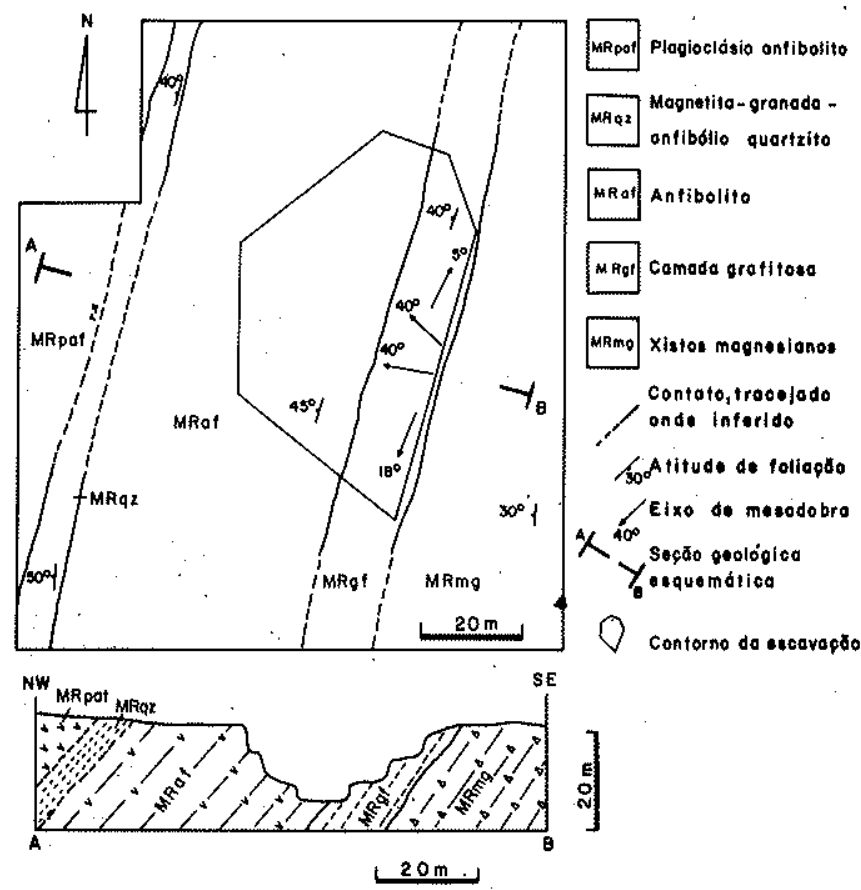

Figura 4 - Geologia do Garimpo Filó (ver localização na figura 3)

gados e orientados segundo $S_{1}$, indicando que os sulfetos são pré e sin-tectônicos em relação a $F_{1}$ (Prancha 1, Foto 2). $\mathrm{Na}$ seção de concentrado de minerais pesados a pirita é o sulfeto dominante, ocorrendo em grãos com eventuais inclusðes de calcopirita e pirrotita. Calcopirita e esfalerita são sulfetos subordinados e o último apresenta refle$x$ Xes internas raras e de cor marrom-amarelado que podem conter raras inclusōes de pirrotita. Covelita e/ou digenita ocorrem recobrindo os grãos de pirita, calcopirita e esfalerita. Calcocita é rara, ocorrendo associada à covelita. Ocorre ouro livre em grãos de 50 a 250 mícra. A paragênese e as texturas indicam que a amostra foi coletada na zona de cementação, onde se observa o enriquecimento supergênico do cobre sob forma sulfetada (Cameron 1961).

Mineralização da área de Amaro Leite Serão descritas aqui as mineralizações da porção nordeste da região estu. dada (Fig. 2). Na área em epígrafe predominam rochas da Sequência Mara Rosa, circundadas a noroeste por ortognaisses tonalíticos do Complexo Granito-Gnáissico. Intrusivas máficas, representadas por gabro, hornblendito e diorito, ocorrem em ambas as unidades.

A Seqüência Mara Rosa, encaixante das mineralizações estudadas, pode ser dividida nas seguintes unidades litoestratigráficas:

- Biotita gnaisses: Na área de ocorrência desta unidade os afloramentos são raros e, geralmente, intemperizados. A rocha predominante parece ser um biotita gnaisse de cor 

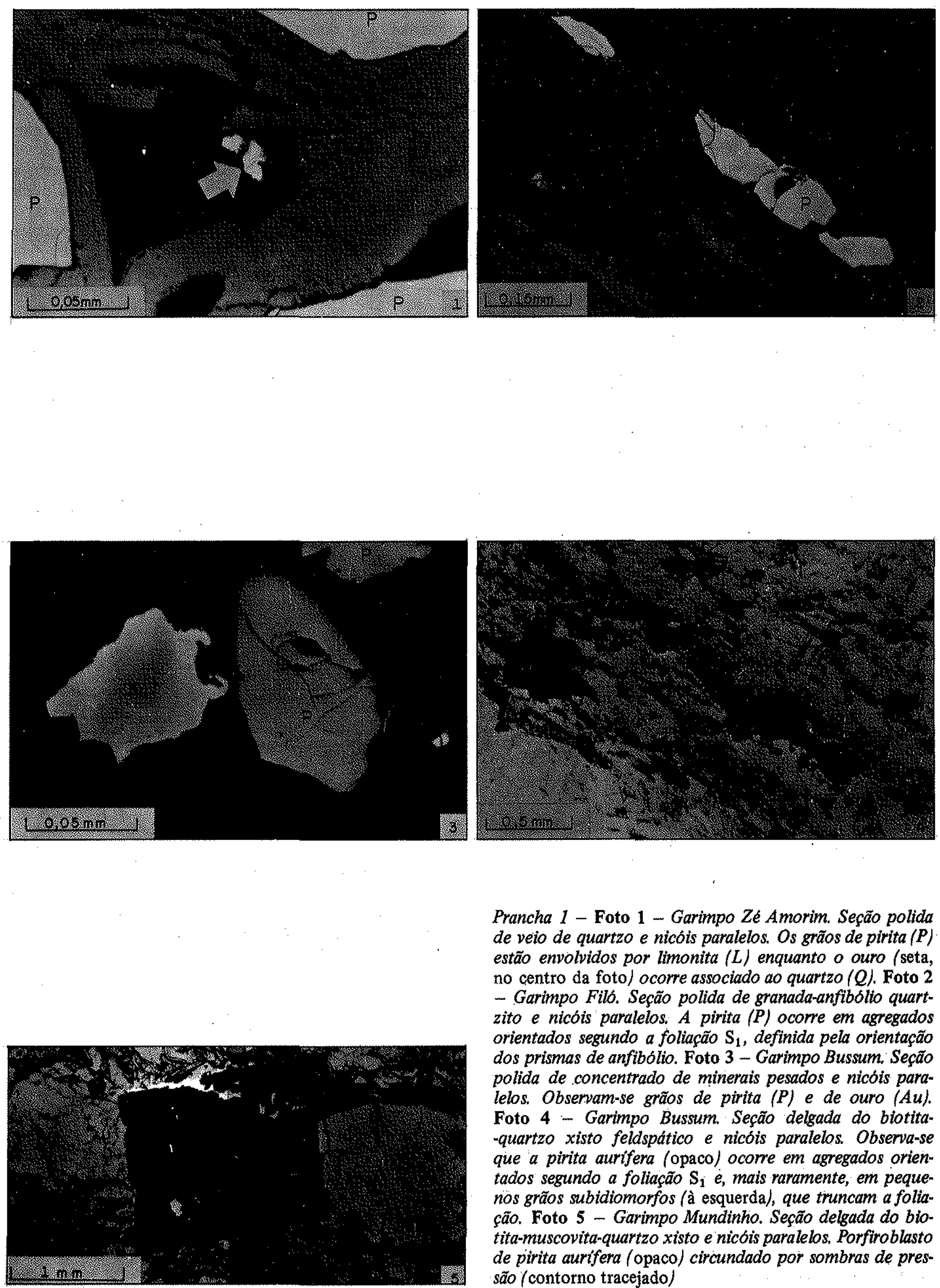

Prancha 1 - Foto 1 - Garimpo Zé Amorim. Seção polida de veio de quartzo e nicóis paralelos. Os grãos de pirita $(P)$. estão envolvidos por limonita $(L)$ enquanto o ouro (seta, no centro da foto/ ocorre associado ao quartzo ( $Q$ ). Foto 2 - Garimpo Filó. Seção polida de granada-anfibólio quartzito $e$ nicóis paralelos. $A$ pirita $(P)$ ocorre em agregados orientados segundo a folią̧ão $\mathrm{S}_{1}$, definida pela orientação dos prismas de anfibólio. Foto 3 - Garimpo Bussum. Seção polida de concentrado de minerais pesados e nicóis paralelos. Observam-se grãos de pirita $(P)$ e de ouro (Au). Foto 4 - Garimpo Bussum. Seção delgada do biotita-quartzo xisto feldspático e nicóis paralelos. Observa-se que a pirita aurifera (opaco) ocorre em agregados orientados segundo a foliação $\mathrm{S}_{1} \dot{e}$, mais raramente, em peque noos grãos subidiomorfos (à esquerda), que truncam a foliação. Foto 5 - Garimpo Mundinho. Seção delgada do biotita-muscovita-quartzo xisto e nicois paralelos. Porfiroblasto de pirita aurifera (opaco) circundado por sombras de pressão (contorno tracejado) 
cinza, granulação fina e textura granolepidoblástica, constituído por quartzo, plagioclásio e biotita, com muscovita e epídoto subordinados, interpretando como um metassedimento arcosiano. Ocorrem anfibolitos como intercalações no biotita gnaisse e, a nordeste de Amaro Leite (Fig. 5), ocorre plagioclásio anfibolito de cor cinza-esverdeado, foliado, com textura porfirítica reliquiar, interpretado como metandesito. Esta rocha tem matriz orientada, de granulação fina, formada por plagioclásio ocasionalmente zonado, hornblenda, quartzo e epídoto. Imersos nesta matriz observam-se fenocristais relictos de plagioclásio de até $5 \mathrm{~mm}$, pré-tectônicos em relação a $F_{1}$, idiomórficos a hipidiomórficos, com geminações segundo as leis da albita e albita-periclínio.

- Epidoto anfibolitos: Nesta unidade predominam epídoto anfibolitos, semelhantes aos que ocorrem na área de Amaralina, interpretados como ortoanfibolitos. Subordinadamente, ocorrem muscovita-biotita gnaisse, sericita-quartzo xistos grafitosos, mica xistos e magnetita quartzito bandado (formação ferrífera bandada).

- Muscovita-cianita-quartzo xistos: São rochas de cor cinza, estrutura foliada e composição à base de quartzo, cianita e muscovita, sendo esta última, geralmente, produto de alteração de cianita.

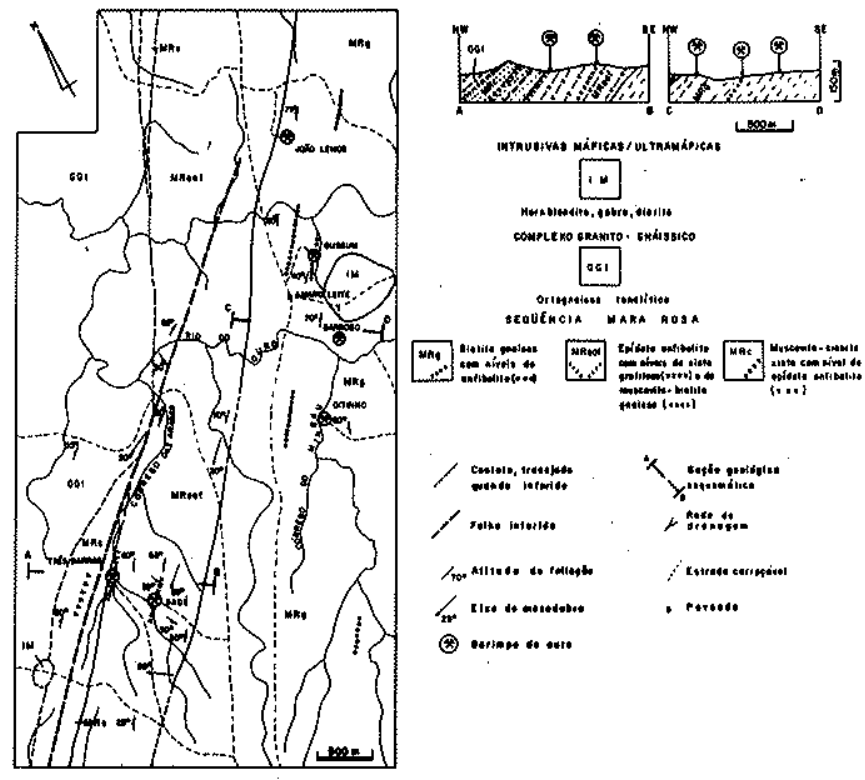

Figura 5 - Geologia da região de Amaro Leite (modificado de Machado et al. 1981, ver localização da área na figura 2)

\section{GARIMPOS DITINHO, BARROSO E JOÃO}

$L E M O S \quad$ Nestes três garimpos a rocha encaixante está intensamente intemperizada $\mathrm{e}$, feita esta ressalva, as mineralizaçð̄es explotadas parecem ser geologicamente semelhantes. As três ocorrências estão encaixadas na mesma unidade li. toestratigráfica, onde predomina o biotita gnaisse já descrito.

Nos garimpos em epígrafe as escavaçð̃es estão, invariavelmente, orientadas a NE, paralelamente ao rumo das unidades litoestratigráficas, que indicam uma natureza stratabound para as mineralizaçőes auríferas. $O$ ouro parece ocorrer disseminado nos muscovita-biotita gnaisses intemperizados, assim como em camadas de espessura pluridecimétrica de quartzitos de cor branca e granulação muito fina, contendo algum sulfeto. Ao microscópio, o quartzito apresenta tex- tura granoblástica, e é constituído quase que somente de quartzo, com opaco e sericita muito subordinados, sendo interpretado como um metachert. A observação de uma seção polida desta rocha revela a presença de pirita em pequenos grãos idiomórfìcos disseminados.

GARIMPO BUSSUM Trata-se de escavação antiga que, segundo Machado et al. (1981), dataria do final do século passado. Quando da realização dos trabalhos de campo, a escavação vinha sendo desentulhada por garimpeiros, numa tentativa de retomar a explotação. A escavação mede cerca de $20 \times 8 \mathrm{~m}$ e sua orientação é quase concordante com o rumo das unidades litoestratigráficas, o que sugere uma natureza stratabound para a mineralização aurífera (Fig. 6). Neste local, afloram anfibolito e biotita-quartzo xisto feldspático, em intercalaçós de espessuras variando entre 0,5 e $3,0 \mathrm{~m}$. O ouro, juntamente com algum sulfeto, ocorre disseminado no xisto.
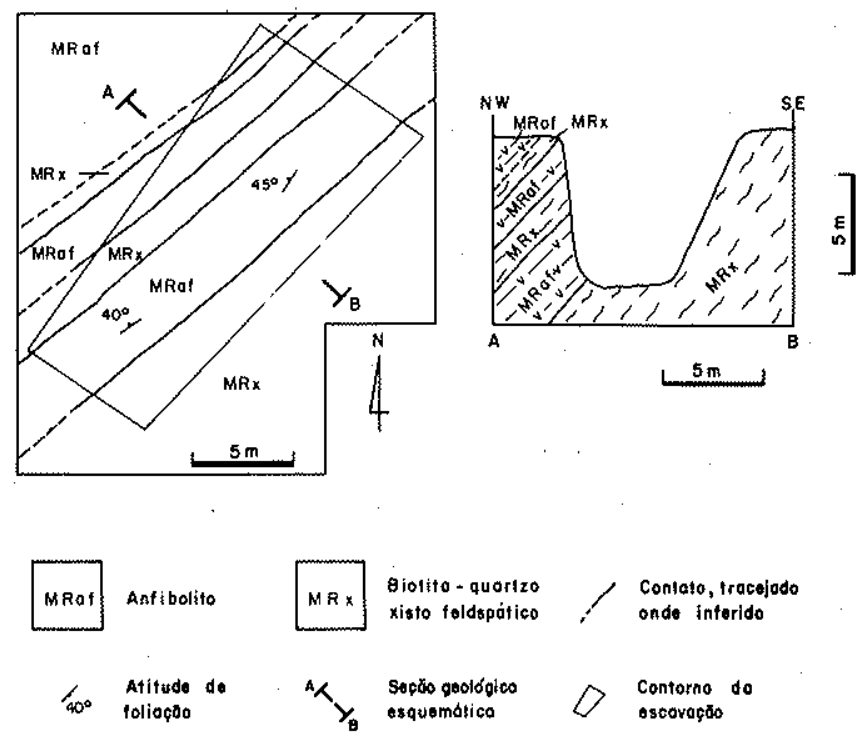

Figura 6 - Geologia do garimpo Bussum (ver localização nas figuras 2 e 5)

$\mathrm{O}$ anfibolito tem cor verde, granulação fina a média e textura nematoblástica pouco orientada. É constituído essencialmente por hornblenda, com epídoto, clorita e tremolita subordinados, sendo os dois últimos minerais resultantes de alteração da hornblenda.

$O$ biotita-quartzo xisto feldspático tem cor cinza-esverdeado, granulação fina e textura granolepidoblástica. E constituído, essencialmente, de quartzo, biotita e plagio. clásio, em proporçōes variáveis, com clorita e epídoto subordinados. Muscovita, carbonato e opacos podem ou não estar presentes. $O$ plagioclásio, freqüentemente zonado, está parcialmente alterado para epídoto e sericita. Estes xistos são interpretados como metatufos intermediários.

Os minerais opacos do biotita"quartzo xisto feldspático foram estudados em seçбes polidas de rocha e de concentrado de minerais pesados. Na seção polida de concentrado predomina a pirita, com freqüentes inclusões ovóides de calcopirita e/ou pirrotita. Ocorre calcopirita também em grãos isolados, assim como ouro livre em grãos com forma irregular, de 10 a 200 mícrons (Prancha 1, Foto 3). Subordinadamente ocorrem ilmenita, esfalerita e magnetita martitizada. Nas seções delgadas e seçőes polidas de rocha, obser- 
va-se que a pirita ocorre, predominantemente, como agregados orientados segundo $S_{1}$, indicando seu caráter pré e sin-tectônico em relação a $F_{1}$ (Prancha 1 , Foto 4). Raramente ocorrem grãos idiomórficos de pirita, que parecem representar porfiroblastos pós-tectônicos em relação a $F_{1}$. Análises químicas de concentrados de pirita mostram que este mineral contém ouro, provavelmente sob forma submicroscópica (Tab. 1), o que implicaria que a mineralização aur ífera também é pré e sin-tectônica em relação a $F_{1}$.

Tabela 1 - Teores de ouro em concentrados de pirita dos garimpos Bussum e Mundinho (abertura com água-régia a quente e análise por absorção atômica)

\begin{tabular}{|c|c|c|}
\hline Ocorrência & Amostra & $\begin{array}{c}\text { Teor de ouro } \\
\text { no concentrado } \\
\text { de pirita (ppm) }\end{array}$ \\
\hline \multirow{2}{*}{ Garimpo Bussum } & HAR-57 & 213,64 \\
\cline { 2 - 3 } & HAR-58 & 3,74 \\
\hline \multirow{2}{*}{ Garimpo Mundinho } & HMR-31 & 13,79 \\
\cline { 2 - 3 } & HMR-32 & 43,80 \\
\hline
\end{tabular}

\section{GARIMPO $B A D E$ A mineralização aurífera é strata-} bound e ocorre em uma camada grafitosa intercalada em epídoto anfibolitos (Fig. 7). Neste local o padrão de afloramentos é determinado por dobras de Fase $F_{3}$, com eixos N45E/15SW.

A camada grafitosa mineralizada é descontínua e apresenta espessura máxima em torno de $5 \mathrm{~m}$. E constituída por alternâncias decimétricas a métricas de sericita-quartzo xisto grafitoso, sericita-quartzo xisto e sericita quartzito. O sericita-quartzo xisto tem cor cinza-escuro, granulação fina e estrutura foliada. A textura é granolepidoblástica e a composição é à base de quartzo, sericita e grafita. Numa seção polida de sericita-quartzo xisto grafitoso observaram-se, além da grafita, grãos disseminados de pirita e de esfalerita.

\section{GARIMPO TRES BARRAS No local aflora muscovita-} -biotita gnaisse de cor cinza-escuro e granulação fina, contendo algum sulfeto. A textura é granolepidoblástica e a composição é à base de quartzo, plagioclásio, biotita, muscovita e epídoto, com carbonato, opaco e titanita subordinados. Observam-se, ainda, grãos dispersos de plagioclásio, de granulação maior que a do restante da rocha, xenomórficos a hipidiomórficos, alterados para epídoto e sericita. Esta rocha parece representar um metatufo intermediário.

A explotação é realizada por meio de um poço com diâmetro de $5 \mathrm{~m}$ e profundidade de cerca de $15 \mathrm{~m}$ e sugere que a mineralização tem a forma de uma chaminé (pipe). 0 outro ocorre em material quartzoso maciço e de cor branca, que contém carbonato e algum sulfeto.

Para o estudo mineragráfico foi preparada uma seção polida do gnaisse e uma seção polida de concentrado de minerais pesados do corpo mineralizado. No corpo mineralizado, o sulfeto predominante é a pirrotita, com calcopirita subordinada ocorrendo em grãos individuais e em inclusðes na pirrotita. No gnaisse observa-se a mesma paragênese, com os sulfetos ocorrendo em agregados alongados segundo a foliação $S_{1}$, indicativos de sua natureza pré a sin-tectônica em relação a $F_{1}$.

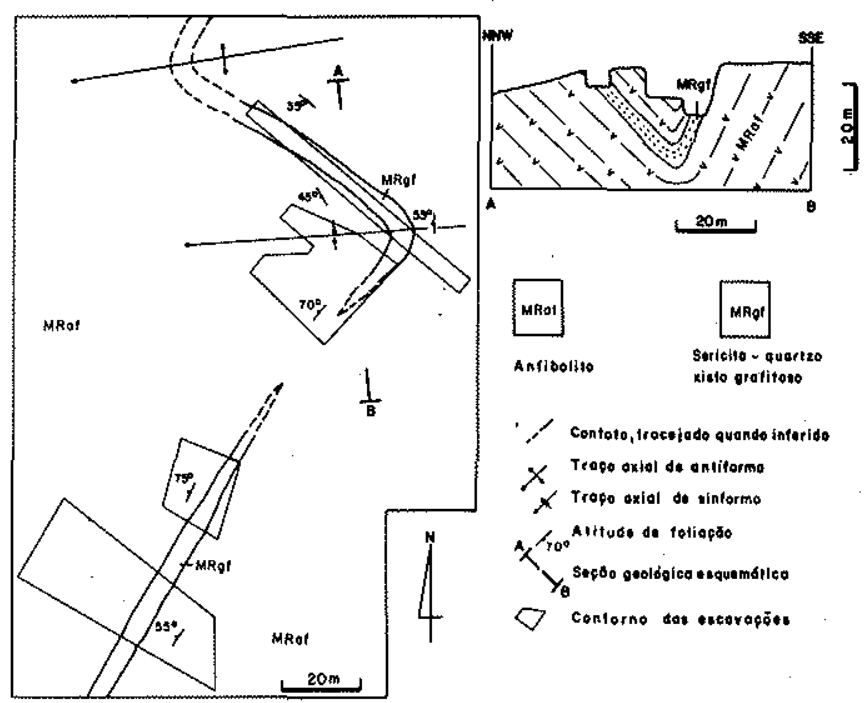

Figura 7 - Geologia do Garimpo Badé (ver localizaçāo nas figuras 2 e 5)

Mineralizaçōes da área do Rio dos Bois Serão descritas aqui as mineralizaçốes da porção sudoeste da área, situadas próximo ao Rio dos Bois (Fig. 2).

\section{GARIMPOS CHICO DE ASSIS, PEDRO COELHO E}

$Z E^{A} N U N E S \quad$ As ocorrências em epígrafe estão situadas na porção centro-sul da área, a sudeste do povoado de Marolândia (Fig. 2).

Entre estas três ocorrências, a mais importante é a do garimpo Chico de Assis, onde a escavação mede $100 \times 50 \mathrm{~m}$, com profundidade máxima de $3 \mathrm{~m}$ e orientação NE. Neste local, a rocha predominante é um granada-muscovita-biotita-quartzo xisto de cor cinza, granulação fina e textura porfiroblástica, interpretado como um metassedimento grauvaqueano. Os porfiroblastos são de granada e a matriz é constituida por quartzo, biotita e muscovita, com epidoto, plagioclásio e carbonato subordinados. Intercalam-se nfveis decimétricos com contribuição vulcanoclástica, caracterizada por grãos de plagioclásio, xenomórficos a idiomórficos, zonados, pré-tectônicos em relação a $F_{1}$, com geminaçôs complexas.

A principal mineralização explotada era constituida por elúvio contendo fragmentos centimétricos a decimétricos de quartzo sacaroidal. A espessura do elúvio parece ter variado entre 1,5 e $3,0 \mathrm{~m}$, tendo sido totalmente explotado na escavação principal. Uma vez esgotado o elúvio, houve explotação incipiente de bolsōes e lentes de quartzo de segregação de espessura decimétrica, intercalados nos xistos e concordantes com $S_{1}$, contendo algum sulfeto. A observação de seçôes polidas mostra que nos xistos acima referidos o sulfeto predominante é a pirita, com inclusóes de pirrotita e ocorrem ainda calcopirita e marcassita subordinadas. Nos bolsðes e lentes de quartzo, predomina a pirrotita enquanto pirita e calcopirita são subordinadas.

Nos garimpos Pedro Coelho e Zé Nunes, a principal mineralização explotada foi o elúvio, que contém concreçðes ferruginosas centimétricas e blocos centimétricos a métricos de quartzo sacaroidal. Nestes garimpos a rocha subjacente está alterada e parece ser representada por muscovita-clorita xistos e mica xistos.

GARIMPOS MUNDINHO E PAULO Nesta área, situada na porção sul da região estudada, foram individualizadas três associações litológicas, descritas a seguir (Fig. 8). 
- Milonitos de composição granitica: São rochas de cores cinza a rosa, granulação média a grossa e estrutura foliada. A matriz é orientada, de granulação fina, constituída por quartzo, feldspato, muscovita, biotita e epídoto, enquanto os porfirociastos são de feldspato potássico e de plagioclásio. Mais raramente, observam-se porfiroclastos de quartzo + feldspato com textura granular.

- Micaxistos: Os litotipos predominantes são muscovita-quartzo xistos e biotita-muscovita-quartzo xistos, de granulação fina, grafitosos ou não. Associados aos xistos ocorrem, localmente, quartzitos a muscovita e/ou biotita, de granulação fina e bandamento milimétrico a decimétrico, devido a presença de faixas mais micáceas que se alternam com faixas mais quartzosas. Localmente esses quartzitos contêm uma provável contribuição vulcanoclástica evidenciada pela presença de grãos de plagioclásio, pré-tectôni$\cos$ em relação a $F_{1}$, xenomórficos a hipidiomórficos, com geminações segundo as leis de albita, albita-Carlsbad e albita-periclínio. Ainda associado aos xistos ocorre orto-anfibolito de granulação fina, no qual os cristais de plagioclásio, zonados, estão arranjados segundo uma textura dolerítica reliquiar.

- Epidosito: Ocorre numa região muito pobre em afloramentos e trata-se de rocha de cor verde, maciça, granulação muito fina, constituída essencialmente por epídoto e hornblenda, com quartzo bastante subordinado.
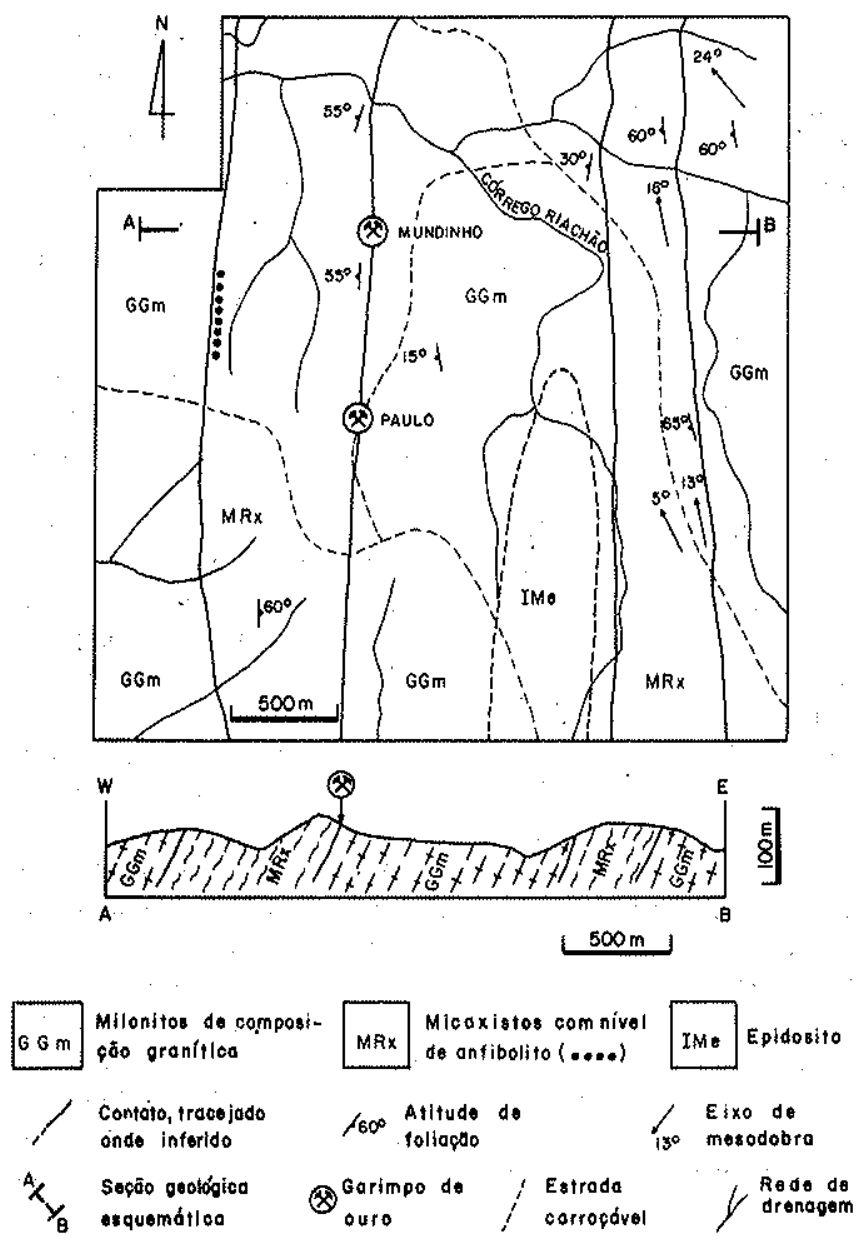

Figura 8 - Contexto geológico dos garimpos Mundinho e Paulo (ver localização da área na figura 2)
A mineralização aurífera ocorre no contato entre uma faixa de mica xistos e uma de milonitos, inserida numa área de $1.000 \times 100 \mathrm{~m}$, com orientação NS, sendo explotada nos garimpos Paulo e Mundinho. A mineralização é geologicamente semelhante nas duas áreas e descreveremos a de Mundinho, onde o grande número de escavações permite uma melhor observação. Neste local, ocorrem faixas de biotita-muscovita-quartzo xisto, intercaladas em milonitos quartzo-feldspáticos, com os quais apresentam contatos bruscos (Fig. 9).

A mineralização aurífera é stratabound e está confinada ao biotita-muscovita-quartzo xisto. A principal faixa mineralizada tem espessura variando entre 0,5 e $3,0 \mathrm{~m}$, tendo sido explotada até a profundidade de $18 \mathrm{~m}$ (Fig. 9). 0 mica xisto é rico em bolsžes e lentes de quartzo, concordantes com a foliação $S_{1}$ e afetados pelas dobras da fase $F_{2}$. Bolsões e lentes quartzosas são atribuídos à segregação metamórfica durante eventos anteriores a $F_{2}$. É possivel, no entanto, que parte das lentes quartzosas representam antigos niveis de chert, totalmente recristalizados. Subordinadamente, observam-se algumas barras de quartzo de comprimento decimétrico a métrico atribuídas à fase $F_{2}$. Bolsões, lentes e barras de quartzo são explotados seletivamente e contêm, localmente, ouro visível. O mica xisto é explotado integralmente, quando rico em lentes centimétricas de quartzo de segregação. Esta rocha exibe cor preta, granulação fina e composição à base de quartzo, muscovita, biotita e opacos, sendo interpretada como um metapelito.

Amostras de canal do garimpo Mundinho, em intervalos de $1 \mathrm{~m}$ na principal camada mineralizada, apresentaram teores de 0,21 ppm, 0,32 ppm e 1,51 ppm de ouro, sendo a análise realizada por absorção atômica após abertura com água-régia a quente.

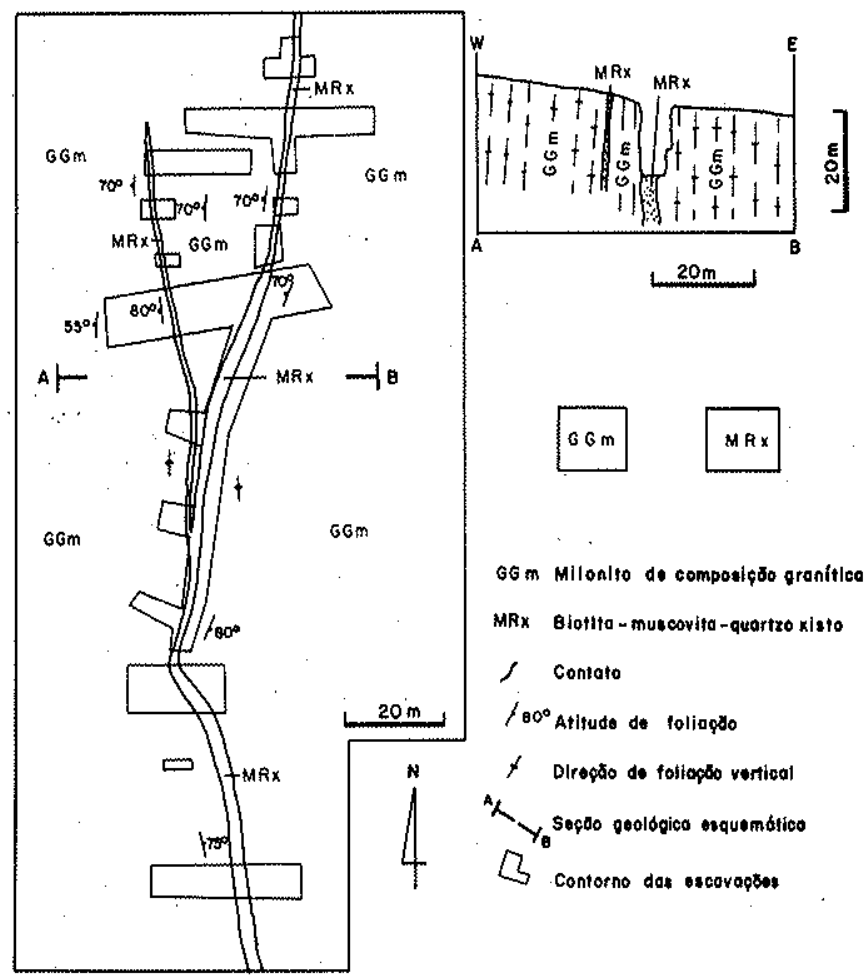

Figura 9 - Geologia do Garimpo Mundinho (ver localização na figura 8) 
A observação de uma seção polida do muscovita-biotita-quartzo xisto mostra que magnetita e pirita são os minerais opacos predominantes; o primeiro ocorre livre de inclusð̃es microscópicas e o segundo pode conter inclusões de calcopirita. Este último mineral é acessório e pode ocorrer também em grãos isolados. A foliação $S_{2}$ é bem desenvolvida nesta rocha e a observação de seções delgadas mostra que a pirita é pré-tectônica em relação a $F_{2}$, estando contornada por sombras de pressão bem desenvolvidas (Prancha 1, Foto 5). Análises químicas de concentrados de pirita mostram que este mineral contém ouro, provavel. mente sob forma submicroscópica (Tab. 1), indicando que a mineralização é pré-tectônica em relação a $F_{2}$. Estas observações microscópicas estão de acordo com as de escala mesoscópica, onde se nota que lentes de quartzo, concor. dantes com a foliação $S_{1}$ e deformadas durante $F_{2}$, são auríferas.

Conforme o exposto anteriormente, os milonitos podem ser interpretados como granitóides deformados enquanto as faixas xistosas representariam megaxenólitos da Sequiência Mara Rosa.

\section{ATIVIDADES DE GARIMPAGEM As atividades de ga-} rimpagem são discutidas aqui com o objetivo de obter dados complementares sobre a geologia das mineralizações estudadas. Essa atividade teve início por volta de 1980 e no final de 1983, no auge, trabalhavam na área cerca de 500 pessoas. A partir de 1984, as atividades de garimpagem entraram em decadência, com a paralisação da grande maioria dos garimpos descritos. Isto pode ser creditado à exaustão do minério, no caso das mineralizações eluvionares, quando os garimpos foram abandonados ao atingir o bedrock. No caso das mineralizações primárias, o abandono dos garimpos pode ser devido à profundidade das escavações, com o conseqüente aumento do custo operacional e da freqüência de desmoronamentos, assim como à crescente dificuldade na cominuição do minério na granulometria adequada à liberação do ouro. Um outro fator a ser considerado é o da atuação dos processos supergênicos sobre as mineralizações primárias. Estes processos podem fazer com que, na zona oxidada, o ouro seja liberado dos sulfetos, tendo até sua granulometria aumentada em relação ao minério não-oxida* do (Boyle 1979). Ainda segundo este autor, pode ocorrer enriquecimento supergênico do ouro na zona de cementação, onde se formam os sulfetos supergênicos. Ambas as situações podem ter ocorrido na região estudada uma vez, que parte do ouro está contida na pirita e, numa das ocorrências estudadas, as escavações atingiram a zona de cementação com enriquecimento supergênico de cobre na forma sulfetada. Vale ressaltar que situação análoga, ou seja, paralisação da explotação uma vez atingido o minério não-oxidado, teria ocorrido em praticamente todas as pequenas minas do greenstone belt de Barberton, na África meridional (Anhaeusser 1966).

Os dados disponíveis indicam teores variando entre $0,2 \mathrm{e}$ $5,0 \mathrm{ppm}$ de ouro para as mineralizações estudadas, obtidos em amostras de canal. Como já foi assinalado quando da descrição das mineralizações primárias, a explotação praticada pelos garimpeiros é bastante seletiva, concentrando-se nas zonas ricas em barras, bolsões e lentes de quartzo de segregação, onde os teores seriam mais elevados que os citados acima
CONCLUSŐES Com base no material mineralizado, as ocorrências foram divididas em: mineralizaçoes secundárias, quando o ouro ocorre em elúvio ou aluvião; e primárias, quando o ouro ocorre no bedrock. Com base na morfologia do corpo mineralizado e em suas relações espaciais com as rochas encaixantes, as mineralizaçőes primárias foram subdivididas em: filonianas, quando o ouro ocorre em veio ou chaminé (pipe) de quartzo ou quartzo + carbonato, sem condicionamento litoestratigráfico; e stratabound, quando, em escala de detalhe, a mineralização está confinada a determinada unidade litoestratigráfica, com o ouro ocorrendo disseminado na rocha e concentrado em barras, bolsőes e lentes de quartzo de segregação. Entre as 14 ocor: rências descritas, nove são primárias stratabound; duas são primárias filonianas e três são secundárias eluvionares.

- A maior parte das mineralizações estudadas está encaixada em rochas da Seqüência Mara Rosa ou em depósitos eluvionares-aluvionares formados às suas expensas. Nesta seqüência destaca-se a faixa que corta diagonalmente a área, com rumo NE e passando por Mara Rosa, à qual está condicionada a maioria das mineralizações primárias, a totalidade das mineralizaçōes secundárias eluvionares e as principais aluvióes auriferas da área.

$\mathrm{Na}$ Seqüência Mara Rosa as mineralizações stratabound são largamente predominantes e foi observada apenas uma ocorrência filoniana. Nas faixas anfibolíticas, resultantes do metamorfismo de metavulcânicas máficas, o ouro ocorre em metassedimentos grafitosos interderrames. Nas faixas com predominância de xistos e gnaisse, representando metassedimentos com freqüente e abundante contribuição tufácea, o ouro ocorre em metachert. e em metatufo intermediário.

O Complexo Granito-Gnáissico é, em relação à Sequiência Mara Rosa, mais pobre em mineralizaçőes auríferas. Nele foram observadas uma ocorrência filoniana encaixada em ortognaisses tonalíticos e duas ocorrências estratiformes em micaxistos, interpretados como megaxenólitos da Seqüência Mara Rosa, englobados por granitóides milonitizados.

As mineralizaçóes secundárias eluvionares ocorrem nas bordas de platôs lateríticos que recobrem rochas da Séquêencia Mara Rosa.

As mineralizaçóes secundárias alưvionares mais importantes ocorrem nos canais de drenagem, em cujas bacias de captação existem mineralizaçōes auríferas primárias encaixadas na Seqüência Mara Rosa.

As mineralizações strätabound da área correspóndem a um modelo descritivo clássico de mineralização aurifera arqueana (Bache 1982). Para estas mineralizaçóes, é proposto um modelo genético em duas etapas: concentração aurífera singenética, de baixo teor, associada a sulfetos de ferro, cobre e zinco; e remobilização desta concentração provo: cando enriquecimentos locais em barras, bolsōes e lentes de quartzo, desenvolvidos durante os eventos tectonometamórficos que afetaram a sequêencia encaixante. A proposta de concentração singenética é apoiada pelo controle estra" tigráfico local, pela natureza sedimentar e/ou tufácea das rochas hospedeiras e pela natureza precoce dos sulfetos que acompanham o ouro. Com efeito, estes sulfetos, às vezes auríferos, são pré-tectônicos e sin-tectônicos em relação a $F_{1}$ e, em uma das áreas descritas, pré-tectônicos em relação a $F_{2}$, indicando que a mineralização aurífera é precoce na história deformacional das rochas encaixantes. A partir do contexto vulcano-sedimentar das mineralizaçós estu- 
dadas, propõe-se que a introdução do ouro na bacia de sedimentação se deu por fenômenos exalativos associados ao vulcanismo (Viljoen 1982). A remobilização destas concentraçð̃es parece ter-se dado principalmente, mas não exclusivamente, durante a fase $F_{1}$. Este modelo genético é, também, clássico na literatura sobre metalogênese do ouro no Arqueano (Viljoen op cit.).

São poucos os dados disponíveis sobre as mineralizaçő filonianas, podendo-se, no entanto, propor uma origem epigenética e um condicionamento a zonas de falha e/ou de maior complexidade estrutural. Para a mineralização filoniana encaixada na Seqüência Mara Rosa, pode-se propor uma origem por remobilização de concentrações auríferas singenéticas contidas nas rochas encaixantes sob ação da tectônica rúptil.

Processos supergênicos podem ter atuado sobre as mineralizações primárias e promovida a liberação do ouro con. tido nos sulfetos e o aumento de sua granolometria na zona de oxidação. $\mathrm{Na}$ zona de cementação, tais processos podem ter levado a um enriquecimento supergênico do metal. Essas possibilidades são sugeridas pela presença de pirita aurífera, existência de enriquecimento supergênico de cobre sulfe- tado e pelo fato de a maior parte dos garimpos ter sido abandonada uma vez atingida a mineralização não-oxidada.

As mineralizações secundárias eluvionares originaram-se pelo enriquecimento, por processos supergênicos, a partir de concentrações auríferas primárias contidas nas rochas da Sequêencia Mara Rosa. Ás mineralizações secundárias aluvionares originaram-se pelo retrabalhamento das mineralizações primárias stratabound, das mineralizações primárias filonianas e das mineralizações secundárias eluvionares.

Agradecimentos $\mathrm{O}$ autor registra seus agradecimentos: ao DNPM, na pessoa do colega Sevan Naves, diretor do VI Distrito Regional, pelo interesse na realização deste estudo; ao $\mathrm{CNPq}$, pela concessão de auxílio à pesquisa (Processo no 403.584-83), que viabilizou a realização dos trabalhos de campo; à Coordenadoria de Fomento Mineral da Metago, pela confecção das seções polidas; ao colega Walter $H$. Schamaltz, cujo apoio tornou possível a realização deste trabalho; aos colegas Maria Abadia da Silva e Daniel Silva da Luz pelas discussões durante a observação de seções delgadas; e à colega Heloísa H.A.B. Silva, pela preparação dos concentrados de minerais pesados e de pirita.

\section{REFERENCIAS BIBLIOGRAFICAS}

ANHAEUSSER, C.R. - 1966 - Supergene gold enrichment in the Barberton Mountain Land with particular reference to the Lily Mine. Witwatersrand, Econ. Geol. Res. Unit, Inform. Circ., $29,16 \mathrm{p}$.

BACHE, J.J. - 1982 - Les gisements d'or dans le monde. Mém. $B R G M, 118,101 \mathrm{p}$.

BOYLE, R.W. - 1979 - The geochemistry of gold and its deposits. Can. Geol. Surv. Bull., 280, 534 p.

CAMERON, E.N. - 1961 - Ore microscopy. New York, John Wiley \& Sons. 292 p.

CAMPOS, E.C.; LACERDA Fo, J.V.; BARRETO Fo, J.A.; COSTA S.A.G. - 1985 - Projeto Ouro-Goiás. Relato das atividades desenvolvidas/1984. Goiânia, MME/DNPM-VI Ds. 175 p.

DANNI, J.C.M. \& FUCK, R.A. - 1981 - Unidades tectono-estratigráficas do embasamento das faixas dobradas na margem ocidental do Cráton do São Francisco. In: SIMPOSIO SOBRE O CRĂTON DO SÃO FRANCISCO E SUAS FAIXAS MARGINAIS, Salvador, 1981. Anais... Salvador, SBG, p. 130-139.

DANNI, J.C.M. \& RIBEIRO, C.C. - 1978 - Caracterização estratigráfica da Sequência Vulcano-Sedimentar de Pilar de Goiás e de Guarinos, Goiás. In: CONGR. BRAS. GEOL., 30. Recife, 1978. Anais... Recife, SBG. v. 2, p. 582-596.

MACHADO, E.C.; MORETON, L.C.; PINHEIRO, M.M. - 1980 Projeto Porangatu, Etapa I, Goiânia, DNPM/CPRM. Rel. inédito, v. 1, 75 p.

MACHADO, E.C. - 1981 - Novas considerações e integração geológica da região de Pilar-Crixás-Mara Rosa-Porangatu. In: SIMPOSIO DE GEOLOGIA DO CENTRO OESTE, GEOLOGIA DO PRÉCAMBRIANO, 1. Goiânia, 1981. Atas... Goiânia, SBG, p. 300-318.

MACHADO, E.C.; SOUZA, C.J.M.; SILVA, M.A.; BERBERT, C.O. - 1981 - Projeto Porangatu, Etapa II. Goiânia, DNPM/CRRM. Rel. inédito, v, 1:253 pp.
MARINI, O.J.; FUCK, R.A.; DANNI, J.C.M.; DARDENE, M.A.; LOQUERCIO, S.O.C.; RAMALHO, R. - 1984 - As faixas de dobramentos Brasília, Uruaçu o Paraguai-Araguaia e o Maciço Mediano de Goiás. In: SCHOBBENHAUS, C. et al. ed. Geolo. gia do Brasil. Brasilia, DNPM, p. 251-355.

RIBEIRO Fo, W. - 1981 - Reavaliação da geologia da regiāo de Pilar Mara Rosa. In: SIMPOSIO DE GEOLOGIA DO CENTRO-OESTE, GEOLOGIA DO PRE-CAMBRIANO, 1. Goiânia, 1981. Atas... Goiânia, SBG, p. 281-296.

RIBEIRO Fọ, W.; COSTA, J.F.G.; ARAUJO, V.A.; VALENTE, C.R.; MACHADO, E.C.; MATOS, S.H.S.; RODRIGUES, E.; VIVIAN, O.; SÄ, A.M.; LIMA, P.F.C. - 1978 - Projeto geologia da regiáo de Pilar-Mara Rosa. Goiânia, DNPM/CPRM. Rel. inédito, v. 1, $150 \mathrm{p}$.

SA, E.F.J. de \& HACKSPACHER, P.C. - 1982 - Revisão sobre análise estrutural, parte I: Conceituação básica e métodos. Ciências da Terra, (5):24-36.

SABOIA, L.A. - 1979 - Os greenstone belts de Crixás e de Goiás GO. SBG - Núcleo Centro-Oeste, Bol. Inf., 9:44-72.

SABOIA, L.A.; TEIXEIRA, N.A.; CASTRO, J.H.G.; TEIXEIRA, A.S. - 1981 - Geologia do greenstone belt de Crixás (GO) e suas implicações geotectônicas. In: SIMPOSIO SOBRE O CRATTON DO SÃO FRANCISCO E SUAS FAIXAS MARGINAIS, Salvador, 1981. Anais..., Salvador, SBG, p. 39.50.

VILJOEN, M.J. - 1982 - The nature and genesis of archean gold mineralization in Southern Africa. Rev. Bras. Geoc., 12(1-3): $522-530$.
MANUSCRITO

Recebido em 28 de novembro de 1985 Revisão aceita em 05 de setembro de 1986

..."os geólogos estão permanentemente diante da tarefa de reconstituir eventos, que aconteceram numa vasta escala e num passado remoto, a partir de vestígios ou produtos desses eventos. Este complexo problema exige a capacidade de raciocinar analogicamente, indutivamente e com imaginação"... 